\title{
TITLE:
}

\section{Optical Properties of LiF in the Extreme Ultraviolet(Abstract_要旨)}

$\operatorname{AUTHOR}(\mathrm{S})$ :

Kato, Riso

\section{CITATION:}

Kato, Riso. Optical Properties of LiF in the Extreme Ultraviolet. 京都大学, 1962, 理学博士

ISSUE DATE:

1962-06-19

URL:

http://hdl.handle.net/2433/210941

RIGHT: 


\section{【 28 】}

氏 名

学位の種 類

学位記番号

学位授与の日付

学位授与の要件

学位論交題目

諭文調査委員

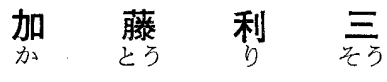

理 学 博 士

論 理 博 第 20 号

昭 和 37 年 6 月 19 日

学 位規則第 5 条第 2 項該 当

Optical Properties of LiF in the Extreme Ultraviolet

（極端紫外に打方弗化リチウムの光学的性質）

(主 查) 教授 内田洋一 教授田中憲三 教授 高橋 熏 教授 富田和久

\section{論交内容 の 要旨}

Alkali-halide 結晶の紫外部基礎吸収の研究はイオン結晶の電子带構造を解明する上にきわめて重要で あり，古くから多くの実験的怙よび理論的研究が行なわれている。従来 Alkali-halide について行なわれ てきた吸収測定はすべて蒸着薄膜を対象としていたため, 結晶の不完全性や表面の污蝕等による影響が避 けがたく，また薄膜の厚み測定の困難さのために吸収係数に関する定量的な知見が得られていなかった。 また LiFについてみ机 Alkali-halide の中で最む簡単な物質であり, 理論的取り扱いも他の Alkali-halide にくらべて容易であるにかかわらず，その基礎吸收带が $1000 \AA$ 以下の極端紫外領域にあるととおよ び適当な礎台がないので蒸着薄膜による吸収測定も困難であり，未だ十分な研究が行なわれていなかった。 著者新たに製作した Seya-Namioka 型の真空分光光度計を用いて LiF 単絬晶の第一励起子帯を反射测 定の方法により研究し，(1) $2000 \sim 900 \AA$ にわたる領域での光学定数 $\mathrm{n}, \mathrm{k}$ および吸収係数 $\mathrm{K}$ の絶対值を決定 し，(2) 励起子帯の理論に怙ける二つの模型(Electron transfer および Excitation 模型) を検討するため 第一励起子带の振動子強度の絶対値を実験的に決定し上記模型の適否を判定した。さらに(3) 極端紫外領 域に抬ける唯一の光学材料として重視されている $\mathrm{LiF}$ 結晶の分光特性および不純物による影響を調べた。

LiF の純粋結晶の製作はかなり困難で著者は自作または輸入した単結晶についてそれぞれ测定を行ない

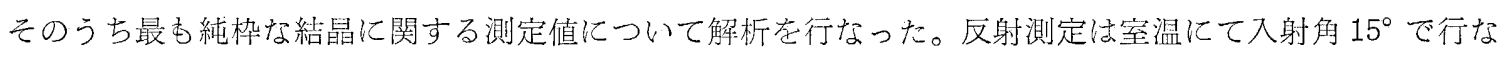
われ，実測值加ら真正反射率在得るため多重反射よる効果の補正を行なった。つぎに反射率 $\mathrm{R}$ をる にKramers-Kroning 関係式を用いて反射に伴なう位相変化 $\theta$ 各波長につき数值積分に上り求め，乙れ

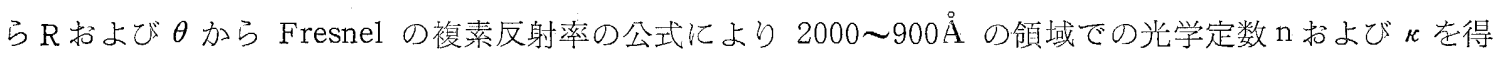
ることに成功した。またッの值から吸収係数 $\mathrm{K}$ を算出し $\mathrm{LiF}$ 第一励起子带の全注うを明らかにしつぎの ような值圭得た。

1）吸収極大波長: $12.7 \pm 0.1 \mathrm{eV}$

2）吸収係数の極大值: $2.2 \pm 0.1 \times 10^{6} \mathrm{~cm}^{-1}$ 
さらに $\mathrm{n}$ および $\mathrm{k}$ から複素誘電率 $\left(\varepsilon=\varepsilon_{1}-\mathrm{i} \varepsilon_{2}\right)$ を求めこのスペクトルを Lorentz の分散公式により解析 し第一励起子帯の振動子強度として

$$
f_{0}=0.4 \pm 0.05 / \text { molecule を得た。 }
$$

この值は动起子の Excitation 模型について Dexter が理論的に 推定した值ときわめて良く一致しており， 著者は Excitation模型のほうが適切であるととを示した。つぎに光学材料としての純䊉LiF 結晶は約 $1050 \AA$ まで透明であるが，空気中で生成した結晶は加水分解による $\mathrm{OH}$ 基の混入のため $1400 \AA$ 以下不透明にな るととを見出し，さらに純䊉結晶であ室温で空気中または水中に放置すると徐々に表面から加水分解され 約 20 日間で $1400 \AA$ 以下の透過度が30\% 程度に低下し飽和状態に達するととを明らかにした。

参考諭文その 1 は主論文の実験に用いた真空分光光度計の試作とその性能について述べたむのであり， その 2 抢よびその 3 は反射測定用クライオスタットの製作とそれによる LiF 結晶の測定を述べた主論文 の前駆的報告である。その 4 およびその 5 は放射線照射を受けた LiF 結晶の極端紫外に抢ける光吸収の変 化と $\mathrm{F}$ 中心抢よび $222 \mathrm{~m} \mu$ 吸収带との関連をのべたすのであり，その 6 は I-イオンを含む $\mathrm{KCl}$ 絬晶につ いてその吸収端に現われる局在励起子吸収に関する新しい発見の報告であり，その 7 は NaI-T1 おょよ゙ $\mathrm{KI}-\mathrm{Tl}$ 燐光体の吸収书よび発光スペクトルからその螢光過程を明らかにしたものである。

\section{論 交 審 查 の 結 果 の 要 旨}

Alkali-halide 結晶の基礎吸収の研究は, 固体内の電子過程を解明する上にきわわて重要であって, LiF 結晶を除いては，すでに若干の研究が発表されている。しかるに， LiF の単一結晶は他の Alkalihalide にくらべ最む遅れて人工的に合成され，またその基礎吸収が極端紫外領域にあるための実験的困難の理由 で十分な研究は全く存在しなかった。著者加藤利三は LiF の光学的性質が実験的にも理論的にあはなは だ興味あることを推察し，まず波長 $600 \AA$ まで使用しうる真空紫外分光光度計を設計試作し，乙れによ って LiF 結晶の基礎吸収端付近の特性を研究した。

著者の試作した分光光度計は Seya-Namioka の理論によるもので, この原理の有効性を初めて実証した。 $\mathrm{LiF}$ 結晶は極端紫外領域で最む透明な物質として知られ，その吸収を調べるとき，その薄膜を蒸着すべき 礎台がない。そこで著者は反射率の測定から出発して, 光学理論によって吸収係数のみならず屈折率をす 導出する方法をとった。すなわち，まず分光光度計を出た各波長について，絬晶の反射光と入射光の強度 比莸求め，てれを実測反射率とした。ついで各種要因を考慮して真正反射率を求奴。著者はての真正反 射率の資料をもとに Kramers-Kronig の関係式を用いて，LiF 結晶の分散，吸光および吸收係数の曲線 を得たのであるが，乙れによって LiF 結晶の第一励起子帯の吸収極大波長を $12.7 \pm 0.1 \mathrm{eV}$ 極大吸収係数 を $2.2 \pm 0.1 \times 10^{6} \mathrm{~cm}^{-1}$ と決定した。

さらに著者は Lorentz の分散公式を適用して第一励起子带の振動子強度の値

$f_{0}=0.4 \pm 0.05 /$ molecule

を得たが，との值は Dexter が励起子の Excitation 模型により推定した理論值に近く，重要な結論であ 万。

参考論文その 1 は著者等が試作した真空紫外分光光度計の内容報告である。その 2 ，その 3 は主論文の 前駆的な意味を有するもの，その 4 ，その 5 は LiF 結晶を $\gamma$ 線， $\beta$ 線で照射した場合に発生する新しい 
中心体の特性を研究したもの，その6は I-イオンを含む $\mathrm{KCl}$ 結晶についてその基礎吸収端に現われる $\mathrm{I}^{-}$ イオンに局在した励起子吸収に関する新らしい結果である。その 7 は KI-Tl, NaI-T1 結晶中の T1 の光 物性的挙動を研究したものである。

とれを要するに，著者の主論文は極端紫外領域に扔ける $\mathrm{LiF}$ 結晶の光学的性質を研究し特に励起子吸 収の位置, 形状, 吸収係数, 振動子強度を決定し, 基礎吸収の理論的考察に重要な資料を呈出したもので あり，参考論交あまた Alkali-halide 内の電子過程に貴重な知見を加えるものである。 よって, 著者の本論文は理学博士の学位論文として価値あるあのと認める。 